\section{Whare Wananga Development in 1993-1994}

\section{PAKAKE CALM WINIATA AND WHATARANGI WINIATA}

\section{Abstract:}

The historical significance of whare wananga to Maori is described and documented. Matauranga Maori is defined and its maintenance, expansion and dissemination (under certain conditions) is offered as the rationale for the existence of whare wananga - past and present. Two wananga which have been established, and one awaiting the process, under the Education Amendment Act 1990, are discussed and, in brief, their characteristics are compared with those of tikanga Pakeha institutions. Some principles of Maori education are suggested. The National Association of Wananga, Te Tauihu o Ngaa Whare Waananga, is introduced, and its priorities for 1995 and beyond are listed. An international perspective is incorporated and a wananga agenda for the future is outlined.

\section{Summary}

This article describes the emergence of whare wananga in the 1980s and 1990s - as the redevelopment of an ancient institution of the Maori; it also provides a commentary on whare wananga development in 19931994.

For those involved in the re-establishment of wananga, the retention, maintenance, expansion and dissemination of various elements of matauranga (knowledge) Maori has been the major motivation.

Matauranga Maori is defined to include tikanga whakaaro (concepts) passed down through generations of Maori and explanations of human behaviour which are predictable from those tikanga whakaaro, regardless of the field of endeavour.

The community of travellers from Rangiatea, aboard their oceanvoyaging canoes, were imbued with the accumulated knowledge of their ancestors on which they would build in Aotearoa.
138 Pakake Calm Winiata and Whatarangi Winiata

With the internationalisation of education and communication systems and the relentless determination of indigenous groups (including Maori) to look to themselves for philosophical sustenance, it is obvious that New Zealand society, and Maori people in particular, would be enriched with more educational options than simply those which were imported by the Pakeha settlers.

The people of Ngati Raukawa, Te Ati Awa and Ngati Toarangatira created their centre of higher learning in 1981 and in doing so provided an option for their own people, for the wider Maori community and for the rest of New Zealand. Subsequently, Te Wananga o Aotearoa and Te Whare Wananga o Awanuiarangi were founded with generally similar intentions.

The Crown produced the Education Act 1989 and, subsequently, the Education Amendment Act 1990, which provided for the creation of "wananga".

With two wananga established (Aotearoa and Raukawa) under the 1990 legislation and one on the doorstep (Awanuiarangi), an association of wananga was created. Te Tauihu o ngaa Waananga o Aotearoa, National Association of Wananga, has identified a number of policy issues which are worthy of serious consideration by both partners to the Treaty of Waitangi. These will be the subject of negotiation in 1995 and beyond.

\section{Whare Wananga}

The establishment of whare wananga on earth is linked to the acquisition of knowledge by the offspring of Papatuanuku (Te Rangihiroa, 1982:448449). According to the Tainui explanations, Tawhaki undertook the journey to receive the three baskets of knowledge (Pei Te Hurinui, 1959:253); other explanations of the same adventure attribute this undertaking to Tane (ibid; Te Rangihiroa, op. cit.:449).

Either way, the concept of whare wananga, a depository for the knowledge acquired by the tupuna (ancestors), is prominent in the explanations of knowledge acquisition, storage and transmission of tupuna Maori (see note).

Evidence to suggest that considerable importance was attributed to whare wananga by those who relocated in Aotearoa from Rangiatea is offered by Pei Te Hurinui in his biography of Potatau. The expression 
140 Pakake Calm Winiata and Whatarangi Winiata

E kore au e ngaro; (I shall never be lost)

He kakanoi ruia mai i Rangiatea; ((I am) a seed broadcast from Rangiatea) reflects the expectation, from which derives the importance.

Table 1 comprises, slightly rearranged, details published by Pei Te Hurinui on whare wananga of Tainui. Some of these were established soon after Tainui Waka arrived which has been dated in the 14th Century (Pei Te Hurinui, 1958). Their curriculum would have centred on the knowledge with which the kakano i ruia mai $i$ Rangiatea was familiar. The development of other whare wananga and curricula followed.

It seems, from descriptions of the activities of Tainui whare wananga by Pei Te Hurinui, that over the centuries, the interaction and coordination between these whare wananga was orderly and comprehensive. Pei Te Hurinui advises (p. 34) that the curriculum of whare wananga o Tainui became

standardised in most respects.

The understanding between the whare wananga is accentuated by Pei Te Hurinui noting that there was an important exception to the standardisation, namely, that

only at Ahurei, Te Papa o Rotu and Rangiatea was the tohi whakauenuku or raising-up ritual of the high priesthood performed, and the meaning of the sacred inscribed stone emblems explained (ibid).

Pei Te Hurinui describes the experience of Potatau Te Wherowhero at Te Papa o Rotu Whare Wananga - 500 years after Hoturoa, the Rangatira (Captain) of Tainui Waka, was discharging his duties as Tohunga Tuahuroa (Grand High Priest) of all of the whare wananga o Tainui - as the opportunity to absorb

all the highest branches of the extensive curriculum of the Tainui whare wananga (ibid:4).

Best, in his monograph on the Maori School of Learning, describes the whare wananga as being concerned with the transmission of higher class knowledge - as opposed to ordinary folk lore. The whare wananga were conservative institutions confined to high ranking tohunga and high ranking families. The maintenance of knowledge in the whare wananga required high powers of memory, as the Maori did not have a written language. Best cites several examples of the highly developed memorising power of the Maori and observes that: the Maori depended entirely on memory, on oral tradition, on verbal teaching, and preserving all prized lore and in passing it on to his descendants (Best, 1976:5).

Table 1 Selection of Whare Wananga o Tainui 1350-1850 (circa)

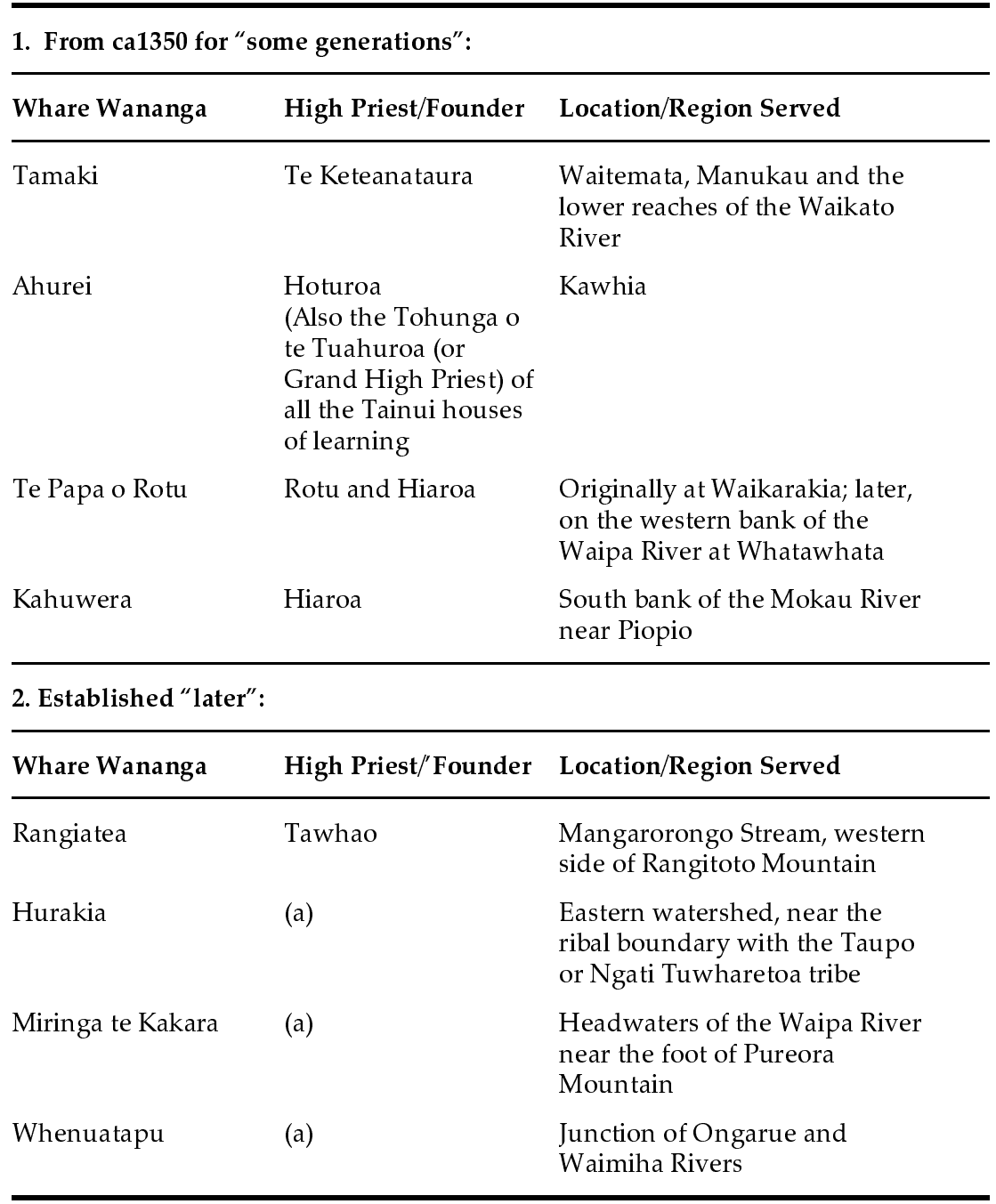

Note:(a) Details not provided by Pei Te Hurinui.

Source: Pei Te Hurinui King Potatau Auckland: The Polynesian Society Inc. 1959. 
Whare wananga were exceedingly tapu institutions; they were responsible for teaching such esoteric knowledge as the relationship between gods and humans. In addition to this content, whare wananga were concerned with historical traditions, tikanga (rules and regulations in this instance), and other material important for the maintenance of Maori society.

The whare wananga took great care in maintaining the purity of the knowledge to be transmitted. Best states

the object of the school of learning was to preserve all desirable knowledge and other traditional lore and to hand it down the centuries free of any alteration, omission, interpolation, or deterioration. Any form of change, any departure from old teachings, was strongly disapproved of and any questioning of ancient teachings was held to be a grievous affront to Tane, the origin and patron of all high-class knowledge (ibid:6-7).

\section{The New Whare Wananga: Background}

In its 1995 Maramataka (Calendar), Te Wananga o Raukawa describes itself (p. 2) as

a reformulation of an ancient institution, the whare wananga and elaborates the original and most senior of which was Rangiatea.

This reference to Rangiatea draws from the identification of Rangiatea by Te Rangihiroa as part of the estate of Io and, in particular as

the sacred house in which the treasures of knowledge were kept (Te Rangihiroa, 1992:446).

The successors of Hoturoa (and of others of Tainui Waka) gave the name Rangiatea to one of their whare wananga (See Table 1).

The founders of Te Wananga o Raukawa, no doubt, were aware that they could never replicate the curriculum of either of the two Rangiatea Whare Wananga - including the "second" to which Ngati Raukawa and Ngati Maniapoto were particularly attached (Pei Te Hurinui, 1959:34). Nor could they hope to reproduce the academic programme of Te Papa o Rotu of which Potatau Te Wherowhero was a student toward the end of the 18th Century - about 500 years after the founding of that Whare Wananga.

The same can be said of the curriculum of Te Wananga o Aotearoa - located squarely among the Ngati Maniapoto and other of Tainui ancestry.
Te Whare Wananga o Awanuiarangi would have the same relationship with its forebears - reformulation, not a replication, particularly as to content.

\section{Te Wananga o Raukawa}

The expression

E kore au e ngaro;

He kakano i ruia mai i Rangiatea

appears on the stationery and publications of Te Wananga o Raukawa. It is a reminder of the matauranga by which the offspring of that seed from Rangiatea are distinguishable.

Another expression to be found among the peoples of Tainui Waka is

Whaia te ara o to tupuna, a Tawhaki,

which is a charge to the younger generations to follow the pathway of their ancestor, Tawhaki who Tainui credit with having acquired the baskets of knowledge from which flow the foundations of matauranga Maori. For the Confederation of Te Ati Awa, Ngati Raukawa and Ngati Toarangatira, the renewed attention to these expressions has been, in part, a consequence of a programme established by the Raukawa Trustees (comprising these three iwi) in 1975 entitled "Whakatupuranga Rua Mano-Generation 2000: An Experiment in Iwi Development". Four principles emerged in the course of designing and promoting Whakatupuranga Rua Mano - Generation 2000. These, which are self explanatory, may be summarised as follows:

- our people are our wealth: develop and retain;

- the marae is our principal home: maintain and respect;

- the Maori language is a treasure: halt the decline and revive it; and

- $\quad$ strive for self determination.

The creation of Te Wananga o Raukawa by the Raukawa Trustees using a simple resolution in April 1981, was part of the experiment which, by that time, had been in existence for five years and had promoted, among other things, 40 to 50 seminars on a number of aspects of matauranga Maori and iwi and hapu development. 
The curriculum of Te Wananga o Raukawa reflects these principles and, of course the establishment of Te Wananga o Raukawa as a degree granting institution was a statement about self determination.

In 1981, Te Wananga o Raukawa had two full-time students and one degree, the Bachelor of Maori and Administration, BMA. For almost a decade, Te Wananga o Raukawa was the only private institution in Aotearoa New Zealand offering degrees. The seven Crown-funded universities, from Otago to Auckland, had been the only degree-granting institutions.

There was no legislation protecting the word "university" or the word "degree" and, although Te Wananga o Raukawa eschewed the use of the word "university", it found it convenient to use the word "degree". However, journalists and others who, for their own reasons preferred to not use the words "whare wananga" would refer to Te Wananga o Raukawa as the "Maori University in Otaki".

Following the establishment of the New Zealand Qualifications Authority under the Education Act 1989, an invitation was extended to Te Wananga o Raukawa to apply to have its degrees approved and the Wananga accredited. The prescriptions were followed and in 1993 the degrees in question were approved and Te Wananga o Raukawa was established under the Education Amendment Act, 1990, and accredited for the purpose of offering those degrees. Since then, further qualifications, including graduate, have been through this process.

\section{Te Wananga o Aotearoa}

Te Wananga o Aotearoa began as Te Awamutu College Marae in 1983, a community organisation in Te Awamutu founded by Rongo Wetere. It then changed names to Waipa Kokiri Arts Centre and offered various short term education programmes to young Maori school leavers of the area. These courses included Maori carving, weaving and tukutuku. Funding for these courses involved the PEP and TAP programmes offered by the Department of Labour.

The organisation developed rapidly, changed its name to the Aotearoa Institute in 1989 and became well known for providing carving and tukutuku for many marae throughout the country.
The type and number of courses expanded during the years from 1987-1992 primarily under the funding systems of ACCESS and MACCESS training programmes, and in 1993 under the Training Opportunities Programme administered by the Education Training and Support Agency. The organisation by 1992 had expanded pan-tribally from the Te Awamutu branch to incorporate campuses in Te Kuiti, Otorohanga, Hamilton, Manukau, Henderson, and, in 1993, a branch campus in Rotorua.

The growth of the organisation is exemplified by the fact that in 1984 the organisation comprised three staff members and 20 students and grew to, in 1994, a staff of approximately 46 and a student number of 400.

A plethora of Training Opportunity Programme and EFTS (Equivalent Full Time Student) funded courses are currently offered in trade skills including Maori arts, design and performing arts, Maori language, computer and business applications, building, plumbing, engineering, media and documentary studies, tourism, work-base experience, and pre-tertiary bridging courses.

\section{Te Whare Wananga o Awanuiarangi}

This wananga was created in 1990 by the Ngati Awa Trust Board which passed its own Act establishing the wananga. Teaching commenced in 1992 with two staff and 60 students. Te Whare Wananga o Awanuiarangi is responsible, through the Runanga o Ngati Awa, to the Ministry of Education. It is an institution serving the four iwi of the Mataatua confederation. In 1993 the wananga acquired PTE (Private Training Establishment) status and organised conduits for funding from the Ministry of Education via the University of Waikato and Waiariki Polytechnic. Until Awanuiarangi is established by the Minister as a wananga under section 162 of the Education Amendment Act 1990, the use of these conduits is the only way to receive funding from the Ministry. Te Whare Wananga o Awanuiarangi has six specific goals upon which its activities are based:

- to provide opportunities for people of the Mataatua region to participate in higher education and learning and to make the experience a rewarding and fulfilling one;

- to assist and encourage students to strive towards te hohonutanga, te whanuitanga $o$ te matauranga (the depth and breadth of knowledge); 
- to help raise educational standards among the people of Mataatua and stimulate interest in tertiary level learning;

- to establish and develop a learning environment which allows students to learn effectively and staff to teach and undertake research that contributes to the body of knowledge of this nation;

- to enhance the integrity of Maori culture in the region, to combat racism with knowledge and to encourage positive attitudes towards cultural diversity; and

- to develop Te Wheke a Toi (the octopus of Toi) concept of reaching out into the international world for ideas and knowledge.

\section{Matauranga Maori}

It is appropriate that some space in this article be given to consideration of the meaning and scope of matauranga Maori.

The ancient whare wananga were concerned to maintain, advance and, to a limited extent, disseminate matauranga Maori. The new whare wananga have the same concern but, probably, are less restrictive as to the dissemination of matauranga.

We have chosen to describe matauranga Maori as:

- tikanga whakaaro which have been passed down through generations of Maori; and

- explanations of human behaviour which draw on, are predictable from and are consistent with those tikanga whakaaro.

Te reo Maori (the Maori language), obviously, must be part of matauranga Maori. By definition it is a collection of linguistic concepts handed down through generations of Maori. Moreover, it is the medium through which those and other concepts are explained and expressed. Translations are approximations; they cannot, ever, be the real thing. Consequently, any curriculum which claims to reflect matauranga Maori must have te reo Maori as the centrepiece of its curriculum and a medium of instruction.

It follows that forms of art which draw on te reo Maori for their expression, including waiata (sung poetry), whakatauki (proverbs), karanga (formal calls by women), whakapapa (genealogy) and whaikorero (formal speech-making) are matauranga Maori-and part of that body of knowledge under threat of decline, as we have been reminded by Hirini Moko (Mead, 1983:339).
Explanations of atua (gods) with reference to their interrelationships with each other, their associations with the human being and links to natural phenomena have been passed down, through generations of Maori. Explanations of these structures, as well as the structures themselves, are part of matauranga Maori.

Whanau (family) relationships are captured in te reo Maori in distinctive ways and they are part and parcel of explaining certain types of behaviour between individuals and between groups. Whanau, hapu, iwi and waka are among the players and hypotheses about their behaviour, including their maintenance, arise, of course, from concepts of whanaungatanga (familiness) passed down through generations of Maori to the current kaumatua.

Cleve Barlow (1993) has authored a book entitled Tikanga Whakaaro: Key Concepts in Maori Culture in which he lists and describes, in Maori and in English, 70 tikanga whakaaro. The text reflects the emergence of ideas across generations of Maori - including the more recent. For example, his material on karakia reflects the embodiment of Christian concepts which, since Ruatara brought Marsden to his people at Oihi, have had a significant impact on many aspects of matauranga Maori (Anglican Church:i(a)).

Matauranga Maori (and its epistemology) is not time bound - neither in its origins, nor in its evolution. This point is important with respect to understanding the new whare wananga - for, those subjects listed in Table 2, which are offered by Aotearoa, Awanuiarangi and Raukawa, have, to a greater or lesser extent, foundations in matauranga Maori.

The foregoing is about the content of education in matauranga Maori. What about the process? And, what about both content and process? Some principles which have implications for the way in which Maori education is organised and developed, can be stated.

1. There are concepts which have been passed down through generations of Maori from before and since te kakano settled in Aotearoa New Zealand; there is no starting date, nor is there a finishing one for the passage of matauranga Maori.

2. The teaching of these concepts and of the inferences which can be drawn from them, if not done, at least in part, in te reo Maori, will involve approximations purely because one language (Maori), and the concepts which it conveys better than any other language, cannot be substituted exactly by any other. This is a truism. 
Table 2 Te Wananga O Aotearoa, Te Whare Wananga O Awanuiarangi, Te Wananga O Raukawa, 1994

\begin{tabular}{|c|c|c|c|c|}
\hline Wananga & Certificate & Diploma & $\begin{array}{c}\text { Degree } \\
\text { (Bachelors) }\end{array}$ & $\begin{array}{l}\text { Post-Grad } \\
\text { (Masters) }\end{array}$ \\
\hline \multirow[t]{8}{*}{$\begin{array}{l}\text { Te Wananga o } \\
\text { Aotearoa }\end{array}$} & Arts \& Design & $\begin{array}{l}\text { Sports \& } \\
\text { recreation }\end{array}$ & $\mathrm{n} / \mathrm{a}$ & $\mathrm{n} / \mathrm{a}$ \\
\hline & $\begin{array}{l}\text { Performing } \\
\text { Arts }\end{array}$ & $\begin{array}{l}\text { Arts \& Design } \\
\text { (three-year) }\end{array}$ & & \\
\hline & Te Reo & Performing Arts & & \\
\hline & $\begin{array}{l}\text { Computer \& } \\
\text { Business }\end{array}$ & & & \\
\hline & Building & & & \\
\hline & Plumbing & & & \\
\hline & Engineering & & & \\
\hline & $\begin{array}{l}\text { Media \& } \\
\text { Documentary }\end{array}$ & & & \\
\hline \multirow[t]{3}{*}{$\begin{array}{l}\text { Te Wananga o } \\
\text { Awanuiarangi }\end{array}$} & $\begin{array}{l}\text { Iwi } \\
\text { Development } \\
\text { courses }\end{array}$ & $\begin{array}{l}\text { Maori Studies } \\
\text { Te Reo }\end{array}$ & Maori Education & Maori Studies \\
\hline & & $\begin{array}{l}\text { Maori } \\
\text { Leadership }\end{array}$ & Maori Studies & $\begin{array}{l}\text { Indigenous } \\
\text { Studies }\end{array}$ \\
\hline & & $\begin{array}{l}\text { Teaching } \\
\text { (three-year) }\end{array}$ & & \\
\hline \multirow[t]{6}{*}{$\begin{array}{l}\text { Te Wananga o } \\
\text { Raukawa }\end{array}$} & $\mathrm{n} / \mathrm{a}$ & $\begin{array}{l}\text { Awa, Raukawa } \\
\text { Toarangatira- } \\
\text { tanga }\end{array}$ & $\begin{array}{l}\text { Maori \& } \\
\text { Administration }\end{array}$ & $\begin{array}{l}\text { Matauranga } \\
\text { Maori }\end{array}$ \\
\hline & & Maori Studies & $\begin{array}{l}\text { Hapu } \\
\text { Development }\end{array}$ & \\
\hline & & Design \& Art & $\begin{array}{l}\text { Laws \& } \\
\text { Philosophy }\end{array}$ & \\
\hline & & $\begin{array}{l}\text { Maori Health } \\
\text { (Post Basic) }\end{array}$ & Health Studies & \\
\hline & & & Design \& Art & \\
\hline & & & $\begin{array}{l}\text { Matauranga } \\
\text { Maori }\end{array}$ & \\
\hline
\end{tabular}

3. In Aotearoa New Zealand, the heritage is bicultural (including Maori) and the educational process can be enhanced by using another language as well as Maori to diminish the problem of approximation in rendering into te reo Maori concepts which can be described as having been passed down through generations other than Maori or which have been developed, possibly contemporaneously, by others.

4. Whare wananga may choose to conduct their affairs totally in te reo Maori and work, with Te Taura Whiri i te Reo Maori (Maori Language Commission) and others, on diminishing the "approximation problem" by expanding the scope and use of te reo Maori.

5. Kuia (female elders), koroua (male elders) and matua (parents and relations of that generation) are, by and large, the only repositories of the exclusive knowledge relevant to the maintenance of their whanau, hapu and iwi; it follows that they must be the principal kaiwhakaako (teachers). The greater the separation of this group (of kuia, koroua and matua) from the education process in which their offspring are involved, the greater the risk that the educational content and process will be irrelevant to the maintenance of their whanau, hapu and iwi.

\section{Educational System in Aotearoa New Zealand}

We enhance the quality of life by expanding the options for human pursuit and development. The re-establishment of wananga, the rediscovery of knowledge and the creation of new knowledge all in the process of teaching and research under the direction and management of people knowledgeable in tikanga Maori have expanded the options available to the citizens of Aotearoa New Zealand. Although admission is unrestricted, descendants of the kakano who came from Rangiatea far outnumber those of other ancestry, Pakeha et al., on the student rolls of the new wananga.

Over the years, the educational institutions in Aotearoa New Zealand have placed emphasis on equality of opportunities - in contrast to equality of results. Implicit, it seems, has been the presumption that schools, universities and other educational institutions in Aotearoa New Zealand were erected and conducted on level playing fields in terms of their relevant cultural imperatives. Those whose origins are from tikanga Pakeha (all things Pakeha) might have experienced this; those who trace themselves to tikanga Maori (all things Maori) would, in all probability, disagree. The inequality of results would support their position. 
Whare wananga, based on matauranga Maori and rooted in tikanga Maori, are very different institutions from the universities and other tertiary organisations established by Pakeha which, naturally, are founded on tikanga Pakeha. The grafting of tikanga Maori onto these institutions has been unsuccessful and is likely to continue to be so.

The re-establishment of whare wananga has provided for the most obvious environments in our learning institutions to be traceable to tikanga Maori.

For a whare wananga, the physical environment, the linguistic environment, the curriculum, the administrative procedures and the external responsibilities are markedly different from those of tikanga Pakeha institutions.

The movement toward the re-establishment of whare wananga is an initiative of the Maori people. Their concerns for all things Maori, including development, are matched with similar movements abroad. Articles 15 and 16 of the latest Draft Declaration on the Rights of Indigenous People (1993) are prescriptions for the retention, maintenance, expansion and dissemination of indigenous knowledge and for indigenous world views to be acknowledged (United Nations, 1994).

All three Wananga that are currently operating were established by iwi and are administered according to tikanga Maori, with the application of knowledge regarding ahuatanga Maori central to the academic programmes. These characteristics of Wananga are distinctive and unique in the tertiary sector.

Wananga have been established to promote teaching and research in Matauranga Maori, including te reo, tikanga, hapu and iwi development, hapu and iwi resource management and to disseminate such knowledge for the social, cultural and political development of hapu and iwi.

Wananga are an iwi initiative to establish a successful tertiary model to address the educational gap between Maori and non-Maori, by providing Maori access to quality education and employment opportunities. Wananga are immediately accountable to their establishing iwi.

Although the focus of Wananga is to address Maori educational needs, all Wananga have an open door policy for all students irrespective of tribal or ethnic origins.

Wananga are to be considered as part of a natural path of progression for Maori that begins with Te Kohanga Reo and moves to
Kura Kaupapa Maori at the primary and secondary levels.

Wananga contribute to maintenance of the specific knowledge of the iwi that established the Wananga. An important aspect of fulfilling this role is the involvement of kaumatua, kuia and koroua, in the delivery of programmes and the maintenance of standards.

An important context within which the Wananga continue to deal are the learning and social needs of the student populations. There are inherent difficulties in working with a marginalised group who face not only Maori cultural difference in learning, but socio-cultural and economic barriers. The incidence of poverty, long term unemployment, family and social problems are, no doubt, higher at Wananga than at other institutions.

A significant thrust of Wananga activity is research into matauranga Maori and issues affecting the social, cultural, economic and political development of hapu and iwi.

\section{Legislation}

With the emergence of kohanga reo, the establishment of kura kaupapa Maori and nearly a decade of experience with Te Wananga o Raukawa, it was clear as we approached the end of the 1980s that those people who had been working within these tikanga Maori institutions meant business. They had demonstrated that education in, and within, tikanga Maori was wanted by the Maori partner to the Treaty of Waitangi; moreover, it was clear that the same partner was determined that it would happen with or without adequate funding.

In 1990, the New Zealand Planning Council published a collection of Essays by Maori including one by Linda Smith, a Senior Lecturer in Education at Auckland University, entitled Maori Education - A Reassertion (Smith, 1990) in which she described the emergence of these tikanga Maori educational institutions in the 1980s. The title was well chosen and the message from many Maori educators which is reflected in the article is absolutely clear: tikanga Maori educational institutions are wanted.

Meanwhile the United Nations had promoted and supported a working party on indigenous rights whose work had been progressing during the decade of the eighties. This Working Group of the United Nations produced at its Eleventh Session a Draft Declaration on the Rights of Indigenous Peoples 1993. We are particularly interested in Articles 15 and 16: 
Article 15

Indigenous children have the right to all levels and forms of education of the State. All indigenous peoples also have this right and the right to establish and control their educational systems and institutions providing education in their own languages, in a manner appropriate to their cultural methods of teaching and learning.

Indigenous children living outside their communities have the right to be provided access to education in their own culture and language.

States shall take effective measures to provide appropriate resources for these purposes.

\section{Article 16}

Indigenous peoples have the right to have the dignity and diversity of their cultures, traditions, histories and aspirations appropriately reflected in all forms of education and public information.

States shall take effective measures, in consultation with the indigenous peoples concerned, to eliminate prejudice and discrimination and to promote tolerance, understanding and good relations among indigenous peoples and all segments of society.

What might be described as the establishing paragraphs of the Education Amendment Act 1990, namely section 162(4), appear as an appendix to this chapter. It includes a subsection in which we find a statutory definition of wananga which is as follows

a wananga is characterised by teaching and research that maintains, advances, and disseminates knowledge and develops intellectual independence, and assists the application of knowledge regarding ahua tanga Maori (Maori tradition) according to tikanga Maori (Maori custom).

These establishing paragraphs make it clear that colleges of education are to be established with an orientation in their teaching, research and service roles toward providing teachers and other support for the education sector. Polytechnics, universities and wananga are given wider briefs in the traditional prescriptions to maintain, advance and disseminate knowledge. The statute anticipates, however, that universities be concerned, presumably relative to polytechnics, with

more advanced learning

and with the development of

intellectual independence.
Wananga is the only one of these four categories of institutions given particular responsibility in the field of

ahuatanga Maori (Maori tradition) according to tikanga Maori (Maori custom).

A further distinction between wananga and the other three categories of tertiary bodies is that no protection of the title "wananga" is provided for; this leaves the others free to use this label - as many do. There is a difficulty here. They are tikanga Pakeha institutions and do not have a whakapapa (ancestry) to whare wananga.

Wananga deliver an education in and within tikanga Maori. This cannot be said about the brother and sister institutions dealt with in section 162 of the Education Act 1989.

This matter and certain other issues, including financing and making provision for wananga to exercise tino rangatiratanga, are on the agenda for joint meetings of the legislators and wananga.

Te Wananga o Aotearoa and Te Wananga o Raukawa have been established; Te Whare Wananga o Awanuiarangi was going through the process at the end of 1994 when this article was prepared.

The Ministry of Maori Development has been engaged in the task of shaping up educational policies for Maori at the tertiary level. With respect to wananga, they suffer from the difficulty of not having had hands-on experience with their design and operation.

One idea which this Ministry has floated, and to which a strong negative response has been delivered, is the establishment of a pan-Iwi national wananga. Such a creation would fly in the face of the diversity of tikanga, kawa, dialect, literature, history and so on, across Iwi and the general desire to retain, maintain, expand and disseminate their own. A national organisation, such as Te Pihopatanga o Aotearoa with research and teaching taapapa ("nurseries") in different parts of Aotearoa New Zealand and with its experience in the provision of ministry in diverse iwi and hapu situations, could promote a national wananga with success. It has a proposal, at an advanced stage of preparation, to do this.

Inequity in the provision of funding by the Crown will lead to heightened tension in 1995. The position taken by the Crown not to provide establishment grants to wananga and to maintain wananga on the lowest possible cost category for EFTS funding, is likely to cause the filing of a claim to the Waitangi Tribunal; alternatively, an application to the High Court for judicial review. 


\section{The New Whare Wananga 1993-1994}

The foregoing provides the philosophical, legislative and social context within which Aotearoa, Awanuiarangi and Raukawa have been created and in which they are forging a place for whare wananga in the educational community of this nation and of the world.

The curriculum and qualifications offered by each of the wananga written about in this note, are presented in Table 2. Aotearoa offers more diversity in content than Awanuiarangi or Raukawa; and it presents certificate and diploma studies (including a three-year diploma). It has not sought to promote degree studies - yet.

Awanuiarangi and Raukawa have one-year and three-year diplomas, undergraduate degrees and graduate studies on offer.

Not only does Aotearoa present a more diverse schedule of subjects, it makes its services available at more locations than do Awanuiarangi or Raukawa. Table 3 provides information on this comparison.

Table 4 comprises data on EFTS numbers - past, present and prospective. The projected growth rates are substantially in excess of the national average.

Table 5 is also concerned with EFTS numbers and in particular, comparisons between EFTS on the ground and being taught and the EFTS for whom funding is being received. In 1994, in the case of each of Aotearoa and Raukawa, the ratio of actual EFTS to EFTS for whom funding was received was just above 1.60: 332/200 for Aotearoa and 132/81 for Raukawa. For Awanuiarangi, the ratio was just over unity: $130 / 125$.

Information on staffing is presented in Table 6. Aotearoa retained 46 paid staff - far above the 7.5 and 8.7 for Awanuiarangi and Raukawa, respectively. By comparison, these two relied more on voluntary personnel, especially Raukawa with $48+$ contributing. This reflects the history of Raukawa - of having to operate for several years without funds but with strong support for the kaupapa (principle) of wananga development.

A visit to each of their centres particularly in the case of Aotearoa, will confirm that the physical environment, especially the artwork, reflects concepts passed down through generations of Maori.

The linguistic environment - particularly in certain classrooms, to lesser extent in the administrative areas, but certainly in receiving people - gives prominence to te reo Maori.
Table 3 Wananga: Main Sites and Campuses 1994

\begin{tabular}{lll}
\hline \multicolumn{1}{c}{ Wananga } & $\begin{array}{c}\text { Location of Main } \\
\text { Site }\end{array}$ & Campuses \\
\hline Te Wananga o Aotearoa & Te Awamutu & $\begin{array}{l}\text { Hamilton, Henderson, } \\
\text { Manukau, Rotorua, } \\
\text { Taumarunui, Te Kuiti }\end{array}$ \\
$\begin{array}{l}\text { Te Whare Wananga o } \\
\text { Awanuiarangi }\end{array}$ & Whakatane & Manukau \\
Te Wananga o Raukawa & Otaki & Lower Hutt, Porirua \\
\hline
\end{tabular}

Table 4 Wananga, EFTS Funding in 1994, 1995 and Annual Projections 1996-2000

\begin{tabular}{lccccccc}
\hline \multicolumn{1}{c}{ Wananga } & \multicolumn{7}{c}{ EFTS - Funding Projections } \\
\hline \multicolumn{1}{c}{ Year } & $\begin{array}{l}\mathbf{1 9 9 4} \\
\text { Paid }\end{array}$ & $\begin{array}{c}\text { 1995 } \\
\text { Approved }\end{array}$ & $\mathbf{1 9 9 6}$ & $\mathbf{1 9 9 7}$ & $\mathbf{1 9 9 8}$ & $\mathbf{1 9 9 9}$ & $\mathbf{2 0 0 0}$ \\
\hline $\begin{array}{l}\text { Te Wananga o } \\
\text { Aotearoa }\end{array}$ & 200 & 335 & 600 & 900 & 1350 & 1350 & 1350 \\
$\begin{array}{l}\text { Te Whare } \\
\text { Wananga o } \\
\text { Awanuiarangi } \\
\begin{array}{l}\text { Te Wananga o } \\
\text { Raukawa }\end{array}\end{array}$ & 125 & 133 & 300 & 450 & 675 & 800 & 1000 \\
\hline
\end{tabular}

Administrative procedures make use of concepts of whanaungatanga and emphasise manaakitanga (hospitality), a major source of institutional mana.

The curricula are taught in te reo Maori where possible, and draw on case studies which are traceable to concepts passed down through generations of Maori.

\section{Te Tauihu o Nga Whare Wananga}

A new educational co-operative, comprising representatives of Aotearoa, Awanuiarangi and Raukawa - with provision for other wananga to be represented - has been formed. Its objectives are: 
Table 5 Wananga: Student Numbers 1994

\begin{tabular}{lccc}
\hline & $\begin{array}{c}\text { Number of } \\
\text { Students }\end{array}$ & $\begin{array}{c}\text { Actual } \\
\text { EFTS }\end{array}$ & $\begin{array}{c}\text { EFTS } \\
\text { Funding }\end{array}$ \\
\hline $\begin{array}{l}\text { Te Wananga o } \\
\text { Aotearoa }\end{array}$ & 400 & 332 & 200 \\
$\begin{array}{l}\text { Te Whare Wananga } \\
\text { Awanuiarangi } \\
\begin{array}{l}\text { Te Wananga o } \\
\text { Raukawa }\end{array}\end{array}$ & 230 & 130 & 125 \\
\hline
\end{tabular}

Table 6 Wananga: Staffing in 1994

\begin{tabular}{lcclc}
\hline & \multicolumn{2}{c}{ Paid } & \multicolumn{2}{c}{ Voluntary } \\
\hline \multicolumn{1}{c}{ Wananga } & \multicolumn{2}{c}{ Full Time Equivalent } & Number of Persons \\
\hline & $\begin{array}{l}\text { Admin. } \\
\text { \& Other }\end{array}$ & Teaching & $\begin{array}{l}\text { Admin. } \\
\text { \& Other }\end{array}$ & Teaching \\
$\begin{array}{l}\text { Te Wananga o } \\
\text { Aotearoa }\end{array}$ & 11 & 35 & - & - \\
$\begin{array}{l}\text { Te Whare Wananga } \\
\text { Awanuiarangi }\end{array}$ & 2.5 & 5 & $2(+)$ & $5(+)$ \\
$\begin{array}{l}\text { Te Wananga o } \\
\text { Raukawa }\end{array}$ & 5.2 & 3.5 & $5(+)$ & $48(+)$ \\
\hline
\end{tabular}

1. To facilitate the establishment, growth and achievement of excellence in teaching, learning and research of Wananga.

2. To encourage Wananga to promote teaching and research in the following areas: Matauranga Maori, te Reo, Tikanga, Hapu and Iwi Development, Hapu, and Iwi Resource Development.

3. To encourage and assist Wananga to coordinate, aggregate and disseminate knowledge for the social, cultural and political development of hapu and iwi Maori.

4. To promote unity among Wananga.

5. To help Wananga to protect the mauri and integrity of matauranga Maori.
6. To assist Wananga to achieve high standards of teaching and research.

7. To support Wananga in commenting publicly on matters of general importance.

The establishment of a body to cover wananga as an

approved accrediting agent formalised through appropriate policy and legislative modifications

was anticipated by the Ministerial Tertiary Lead Group in reporting in November 1994 (p. 24). No doubt, Te Tauihu o nga Whare Wananga will seek to have this implemented in 1995.

The priority items on the agenda of Te Tauihu o nga Whare Wananga for 1995 are as follows:

1. To achieve the establishment of Te Whare Wananga o Awanuiarangi under section 162 of the Education Amendment Act 1990.

2. To gain equity with other tertiary institutions in having access to the public purse for (a) establishment funding and (b) operations (in terms of the appropriate EFTS cost categories).

3. To support each other in the pursuit of excellence with respect to teaching, research, management and service to the community.

4. To cooperate in the establishment of an accrediting agent formalised through appropriate policy and legislative modifications.

\section{Future Role of Wananga}

Wananga are determined to develop into economically viable providers of tertiary education, and to meet the roles determined for them by the iwi that established the Wananga. The roles the Wananga will play in the future include:

- promoting the protection and maintenance of and teaching and research in Matauranga Maori, including te reo, tikanga, hapu and iwi development, hapu and iwi resource development;

- developing into a successful indigenous tertiary model to address the educational gap between Maori and non-Maori, by providing Maori access to quality education and employment opportunities;

- being part of a natural path of progression for Maori that begins with Te Kohanga Reo and moves on to Kura Kaupapa Maori at the primary and secondary levels; 
- responding directly to the training and employment concerns of the developing hapu and iwi, by producing graduates who will enhance the quality of decision-making particularly on issues affecting the iwi and hapu but also on matters which have a bearing on the wellbeing of the community at large;

- ensuring the customs and practices of the iwi and hapu that have promoted Wananga are maintained, advanced and disseminated through teaching and research; and

- contributing to various fields of knowledge especially Matauranga Maori both domestically and internationally.

\section{Note}

(This note is provided by the peer reviewer of this chapter, the Right Reverend Muru Walters, Pihopa ki Te Upoko o Te Ika).

There is one aspect in the paper which I suggest requires caution. I offer this as a person who lives and questions aspects of Matauranga Maori. I refer specifically to the section on Whare Wananga acquiring baskets of knowledge. A Matauranga Maori perspective ought to take notice of the oldest and popular version of creation. That story tells of the separation of Rangi and Papa by Tane and resistance from Tawhirimatea. On the other hand the Tainui version is offered which to my mind is a reformulation of the original story where Tane is the original one responsible for separating Rangi and Papa. The Tainui version sees it differently. It locates Tawhaki on a celestial journey to gain the baskets of knowledge from Io who resides in the highest palace of his celestial kingdom. During the ascent Tawhaki has to deal with a very angry Whiro and not with Tawhirimatea. The Tainui version may have developed independently, However its structure bears amazing similarity to the Hebraic version of the seventy amulet angels invoked at the time of childbirth drawn from the book of the angel Raziel. Raziel, like Io is also the holder and transmitter of all knowledge contained in baskets. The rejection of the old version to satisfy a re-worked order for introduced angels and gods may be questioned. If this is done in the name of enlightenment then Whare Wananga will develop into an exciting learning place in the future.

\section{References}

Anglican Church in Aotearoa/New Zealand and Polynesia Constitution.

Barlow, C. Tikanga whakaaro: Key Concepts in Maori Culture, Auckland: Oxford University Press, 1993.

Best, E. The Maori School of Learning, Wellington: Dominion Museum Monograph 6, Government Printer, 1976.

Maramataka 1995. Otaki: Te Wananga o Raukawa, 1995.

Mead, S. M. “Te Toi Matauranga Maori Mo Nga Ra Kei Mua: Maori Studies Tomorrow" in The Journal of the Polynesian Society Vol. 92 No. 3 (September 1983:333-351)

Ministerial Tertiary Lead Group Report. "A Single Harmonised Qualifications Framework", November 1994.

Pei Te Hurinui. "Maori Genealogies" in The Journal of the Polynesian Society Vol. 67, No. 2 (June 1958).

Pei Te Hurinui. King Potatau, Auckland: The Polynesian Society, 1959.

Smith L. "Maori Education - A Reassertion" in Puna Wairere: Essays by Maori, Wellington: NZ Planning Council, 1990.

Te Rangihiroa. The Coming of the Maori, Wellington: Maori Purposes Fund, 1982.

United Nations Working Group Draft Declaration on the Rights of Indigenous Peoples 1993, Wellington: Te Puni Kokiri, 1994.

\section{Appendix: Education Amendment Act 1990 Section 162 (4)}

"(4) In recommending to the Governor-General under subsection (2) of this section that a body should be established as a college of education, a polytechnic, a university, or a wananga, the Minister shall take into account -

“(a) That universities have all the following characteristics and other tertiary institutions have one or more of those characteristics:

“(i) They are primarily concerned with more advanced learning, the principal aim being to develop intellectual independence;

“(ii) Their research and teaching are closely interdependent and most of their teaching is done by people who are active in advancing knowledge; 
“(iii) They meet international standards of research and teaching;

"(iv) They are a repository of knowledge and expertise;

“(v) They accept a role as critic and conscience of society; and

“(b) That -

“(i) A college of education is characterised by teaching and research required for the pre-school, compulsory and postcompulsory sectors of education, and for associated social and educational service roles;

“(ii) A polytechnic is characterised by a wide diversity of continuing education, including vocational training, that contributes to the maintenance, advancement, and dissemination of knowledge and expertise and promotes community learning, and by research, particularly applied and technological research, that aids development;

"(iii) A university is characterised by a wide diversity of teaching and research, especially at a higher level, that maintains, advances, disseminates, and assists the application of, knowledge, develops intellectual independence, and promotes community learning;

“(iv) A wananga is characterised by teaching and research that maintains, advances, and disseminates knowledge and develops intellectual independence, and assists the application of knowledge regarding ahuatanga Maori (Maori tradition) according to tikanga Maori (Maori custom)."

\section{The authors}

Pakake Calm Winiata is Director of Matauranga Maori Studies at Te Wananga o Raukawa; Whatarangi Winiata is Tumuaki of Te Wananga o Raukawa and Professor of Accountancy at Victoria University of Wellington. 